\title{
Seroprevalence of Antibodies to Measles, Mumps and Rubella (MMR) Vaccines in Previously Vaccinated Human Immunodeficiency Virus-Infected Children and their Control Counterparts
}

\author{
Shahana A Choudhury ${ }^{1^{*}}$ and Fazle Matin ${ }^{2}$ \\ ${ }^{1}$ Department of Pediatrics, Meharry Medical College, Nashville, USA \\ ${ }^{2}$ Medical Director, Central Alabama Comprehensive Health, Inc, USA
}

"Corresponding author: Shahana Choudhury, Associate Professor of Pediatrics, Meharry Medical College, Department of Pediatrics, 1005 Dr. D.B. Todd Jr. Blvd., Nashville, TN 37208, USA, Tel: (615) 327-6332/6856; Fax: 615327 5989; E-mail: schoudhury@mmc.edu

Received date: 22 September 2014; Accepted date: 24 October 2014; Published date: 27 October 2014

Copyright: (c) 2014 Choudhury SA, et al. This is an open-access article distributed under the terms of the Creative Commons Attribution License, which permits unrestricted use, distribution, and reproduction in any medium, provided the original author and source are credited.

\begin{abstract}
Background: Concerns remain regarding immunity to measles, mumps and rubella in HIV-infected children and need for booster doses during later adolescent-hood or young adulthood.

Methods: We evaluated measles, mumps and rubella antibodies in $13 \mathrm{HIV}$ - infected and 13 age-matched control children. All children had received 2 doses of the measles, mumps and rubella (MMR) vaccine. Anti-measles, mumps, and rubella antibody levels were assessed by ELISA at a mean of 30 months in the HIV-infected group and 27 months in the control children, following a second dose of the MMR vaccine. MMR antibodies considered to be protective levels were >1.1 ODR (Optical Density Ratio) for measles and mumps and >9.9 IU/ml for rubella.

Results and Conclusions: Of the thirteen HIV-infected children, only four $(31 \%)(p=0.01)$ had protective level $(>1.11$ ODR) of antibodies to measles and five $(38 \%)(p=0.04)$ had protective level of antibodies to mumps compared to eleven $(85 \%)$ of the thirteen controls. Although the prevalence of protective immunity $(>9.9 \mathrm{IU} / \mathrm{ml})$ for rubella was comparable in HIV-infected and control children, antibody levels were significantly lower $(p=0.01)$ in HIVinfected children compared to their control counterparts. Our study results show that approximately seventy percent of HIV-infected children and adolescents compared to their control counterparts, remain susceptible to measles and mumps, despite two doses of the MMR vaccine. We therefore, recommend that booster doses of MMR vaccine be considered in HIV- infected children and adolescents when exposed to outbreaks of these infectious diseases in the US. Further prospective and larger studies may need to be conducted in HIV-infected children to determine if lower immunities in this group are due to primary vaccine failure or waning immunity.
\end{abstract}

Keywords: HIV; Measles; Mumps; Rubella; Protective antibody; Booster doses

\section{Introduction}

Measles, mumps, and rubella are acute viral illnesses which are classically manifested by fever and other systemic manifestations. Measles and rubella, in particular are characterized by a febrile rash illness, and mumps by an inflammation of the salivary glands. The disease spectra for all these infections can range from a mild disease to the development of severe complications including encephalitis, meningitis, and even death [1-3]; mumps is often complicated by orchitis in both immune-competent and immunocompromised individuals. Concerns remain over the disease severity and mortality rate for all these infections in immunocompromised populations.

Infections caused by these three illnesses can be severe in individuals with impaired cell- mediated immunity, including HIV infections [4-6]. Little data is available regarding anti-measles, mumps, and rubella antibody levels in vaccinated HIV-infected individuals [7-10]; and no published data are available in the United States which evaluate the seroprevalence of measles, mumps, and rubella IgG antibodies in HIV-infected children compared with control children. Recent US outbreaks of measles, mumps, and rubella in vaccinated immune-competent children [11-13] have raised concerns regarding the risk of immunocompromised HIV-infected children, adolescents, and adults contracting these infections and suffering the complications, which include death. Although this study was conducted more than a decade ago, was not published earlier because the data was felt not as important then as it is now to clinicians and scientists given the resurgence of these infectious diseases in the US.

Per the 1989 recommendations of the Advisory Committee on Immunization Practices (ACIP), two doses of combined measles, mumps, and rubella (MMR) vaccines should be administered to all immune-competent children at 12-15 months as a primary series and again at 4-6 years of age as a booster dose. These recommendations are the same for immunocompromised children, including those who are HIV-infected, provided there is no current evidence of severe immunosuppression (CD4 count $<15 \%$ for age or clinical AIDS) [14]. Nevertheless, concern remains over waning immunities in HIVinfected children, adolescents, and adults due to their underlying immunosuppression, and thus their susceptibilities to these infectious diseases. The purpose of this study was to evaluate anti-measles, mumps and rubella antibody levels in convenience samples of HIVinfected and uninfected control children. The goals of the study included an analysis of the risk assessment for HIV-infected children who may be susceptible to these infectious diseases, a determination of 
Citation: Choudhury SA, Matin F (2014) Seroprevalence of Antibodies to Measles, Mumps and Rubella (MMR) Vaccines in Previously Vaccinated Human Immunodeficiency Virus-Infected Children and their Control Counterparts . J Vaccines Vaccin 5: 255. doi: $10.4172 / 2157-7560.1000255$

Page 2 of 5

their need for additional booster doses of the vaccine while their immune systems are still intact, and an assessment determining the need (if any) for larger prospective studies.

\section{Methods}

The Ethics Committee of Interfaith Medical Center in Brooklyn, New York, approved the study protocol. Informed written consents were obtained from the legal guardians of the children. The study was conducted between August 1995 and April 1997.

\section{Subject characteristics}

The selection included a convenience sample of thirteen HIVinfected children from the Pediatric Infectious Disease clinic and an equal number of HIV-uninfected control children matched by age and number of doses of the vaccine from the general pediatric clinic at Interfaith Medical Center. The same cohort of children received the first dose of the vaccine, followed to the second dose and assessment of antibodies.

HIV-infected group: These children were classified according to the pediatric HIV classification system [15] and all were on antiretroviral therapy (zidovudine, dideoxyinosine, stavudine, and/or lamivudine). Four of the thirteen children had been started on a protease inhibitor (ritonavir) because of either clinical or immunologic deterioration. Seven of the thirteen (54\%) exhibited clinical evidence of moderate to severe disease (class B and C), while six of the thirteen (46\%) had evidence of moderate to severe immunologic suppression (CD4 count $<25 \%$ for age (15)).

\begin{tabular}{|c|c|c|c|c|c|c|}
\hline & $\begin{array}{l}\text { HIV } \\
(n=13)\end{array}$ & $\begin{array}{l}\text { Control } \\
(n=13)\end{array}$ & $\mathbf{P}^{*}$ & $\begin{array}{l}\text { HIV } \\
(n=13)\end{array}$ & $\begin{array}{l}\text { Control } \\
(n=13)\end{array}$ & $P^{*}$ \\
\hline $\begin{array}{l}\text { Mean (+SD) } \\
\text { age months } \\
\text { at } \\
\text { vaccination }\end{array}$ & $\begin{array}{l}28 \\
(+16-56)\end{array}$ & $\begin{array}{l}18 \\
(+11.22)\end{array}$ & NS & $\begin{array}{l}63 \\
(+12.78)\end{array}$ & $\begin{array}{l}66 \\
(+20.92)\end{array}$ & NS \\
\hline $\begin{array}{l}\text { Mean (+SD) } \\
\text { age months } \\
\text { at serology }\end{array}$ & & & & $\begin{array}{l}94 \\
(+27.64)\end{array}$ & $\begin{array}{l}94 \\
(+34.74)\end{array}$ & NS \\
\hline $\begin{array}{l}\text { Mean (+SD) } \\
\text { months } \\
\text { vaccination } \\
\text { - serology }\end{array}$ & & & & $\begin{array}{l}30 \\
(+27.61)\end{array}$ & $\begin{array}{l}27 \\
(+21.90)\end{array}$ & NS \\
\hline
\end{tabular}

Table 1: Subject Characteristics. ${ }^{\star}$ Two-tailed t- test.

\section{Primary series and routine booster doses}

Each HIV-infected child received a dose of the combined measlesmumps-rubella vaccine (Jeryl Lynn Mumps Strain, Merck \& Co. Inc. West Point, PA.19486) as their primary series at a mean age of 28 months (range 12-63), while the control children received a dose at a mean of 18 months (range 12-50). All children received booster doses at a mean of 63 months (range 48-99) and 66 months (range 48-122) in the HIV-infected and control groups, respectively. All doses were $0.5 \mathrm{ml}$ and administered intramuscularly via the anterior thigh or arm. None received intravenous immunoglobulin at any point during the study.

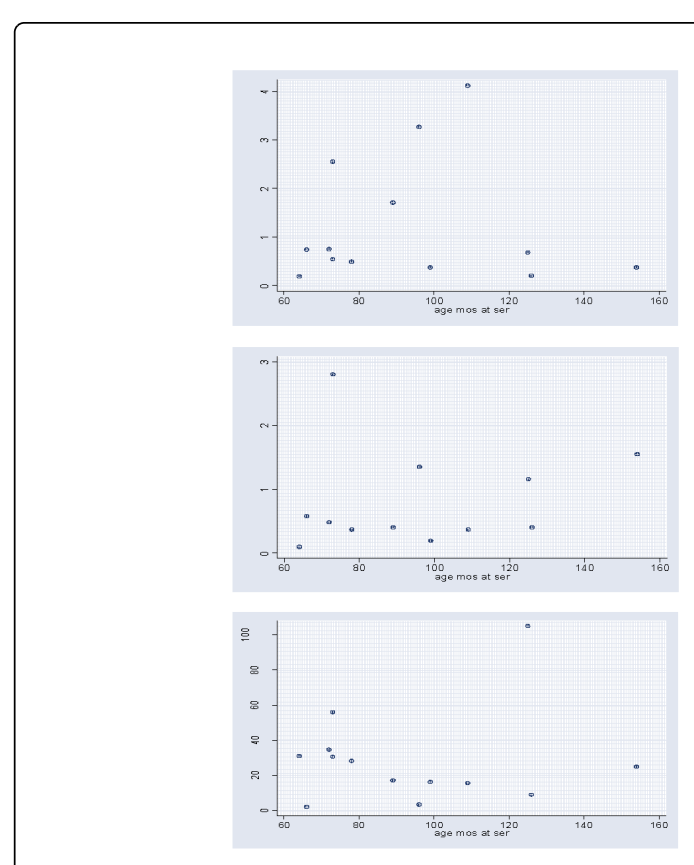

Figure 1: Correlation between age at serology and measles, mumps and rubella IgG in HIV-Infected Children.

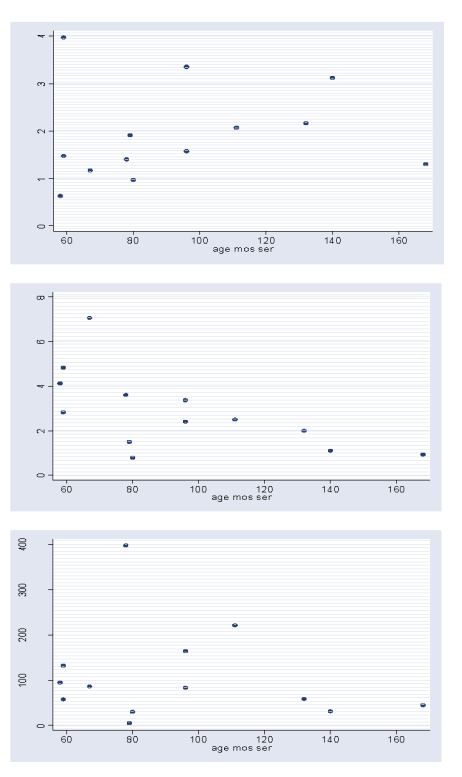

Figure 2: Correlation between age at serology and measles, mumps and rubella IgG in Control Children.

\section{Determination of antibody levels}

Anti-measles, mumps, and rubella antibody levels were drawn from all children at a mean of 30 months in the HIV-infected group and 27 months in the control children following second dose of the MMR vaccine. These antibody levels were measured at Lab Corp, Uniondale, New York, using an enzyme-linked immunosorbent assay (ELISA). 
Citation: Choudhury SA, Matin F (2014) Seroprevalence of Antibodies to Measles, Mumps and Rubella (MMR) Vaccines in Previously Vaccinated Human Immunodeficiency Virus-Infected Children and their Control Counterparts . J Vaccines Vaccin 5: 255. doi: $10.4172 / 2157-7560.1000255$

Page 3 of 5

The level of anti-measles and mumps $>1.11$ Optical Density Ratio (ODR) and of rubella $>9.9 \mathrm{IU} / \mathrm{ml}$ were considered correlates of protection [16-19].

\begin{tabular}{|c|c|c|c|c|c|c|}
\hline \multirow[b]{2}{*}{$\begin{array}{l}\text { Groups }(\mathrm{n}) \\
\text { Total }\end{array}$} & \multicolumn{2}{|l|}{ Measles } & \multicolumn{2}{|l|}{ Mumps } & \multicolumn{2}{|l|}{ Rubella } \\
\hline & $\begin{array}{l}\text { Baseline antibody } \\
\text { (ODR) } \\
\text { Mean } \\
( \pm \text { SD) }\end{array}$ & $\begin{array}{l}\text { Prevalence protection } \\
(\%) \\
(>1.11)\end{array}$ & $\begin{array}{l}\text { Baseline antibody } \\
\text { (ODR) } \\
\text { Mean } \\
( \pm S D)\end{array}$ & $\begin{array}{l}\text { Prevalence protection } \\
(\%) \\
(>1.11)\end{array}$ & $\begin{array}{l}\text { Baseline antibody } \\
(\mathrm{IU} / \mathrm{ml}) \\
\text { Mean } \\
( \pm \mathrm{SD})\end{array}$ & $\begin{array}{l}\text { Prevalence } \\
\text { protection } \\
(\%) \\
(>9.9)\end{array}$ \\
\hline $\begin{array}{l}\text { HIV } \\
\text { (13) }\end{array}$ & $\begin{array}{l}1.23 \\
( \pm 1.28)\end{array}$ & $\begin{array}{l}04 / 13 \\
(31 \%)\end{array}$ & $\begin{array}{l}0.96 \\
( \pm 0.93)\end{array}$ & $\begin{array}{l}5 / 13 \\
(38 \%)\end{array}$ & $\begin{array}{l}28.79 \\
( \pm 27.10)\end{array}$ & $\begin{array}{l}10 / 13 \\
(77 \%)\end{array}$ \\
\hline $\begin{array}{l}\text { Control } \\
\text { (13) }\end{array}$ & $\begin{array}{l}1.93 \\
( \pm 0.99)\end{array}$ & $\begin{array}{l}11 / 13 \\
(85 \%)\end{array}$ & $\begin{array}{l}2.8 \\
( \pm 1.78)\end{array}$ & $\begin{array}{l}11 / 13 \\
(85 \%)\end{array}$ & $\begin{array}{l}108.01 \\
( \pm 105.37)\end{array}$ & $\begin{array}{l}12 / 13 \\
(92 \%)\end{array}$ \\
\hline$P$ & $\mathrm{Ns}$ & $0.01^{\#}$ & $0.002^{*}$ & $0.04^{\#}$ & $0.01^{*}$ & ns \\
\hline
\end{tabular}

Table 2: Anti-MMR Antibodies in HIV- Infected and Uninfected Children. ${ }^{\star}$ Two-tailed t- test. \#Two-tailed Fisher’s Exact test.

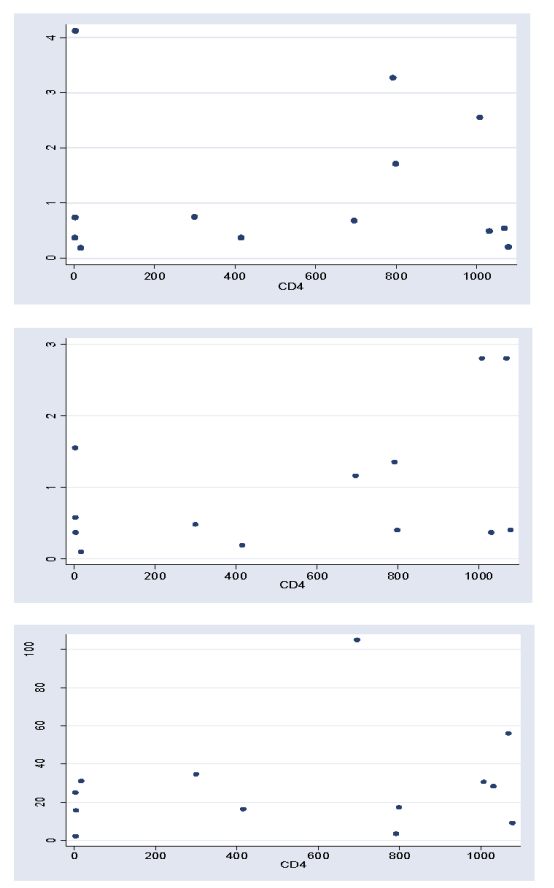

Figure 3: Correlation between CD4 counts and measles, mumps and rubella IgG in HIV-Infected Children.

\section{Immunologic and virologic studies}

$\mathrm{T}$ and $\mathrm{B}$ cell analyses in the HIV group were performed using flow cytometry (Lab Corp, New York) within three months of the serologic assays and HIV viral load measurements by quantitative RNA through polymerase chain reactions (Lab Corp RTP, Triangle Park, NC) within one month of serology. Statistical Analysis

Using the HIV and control groups, the prevalence of protective antibody levels combating measles, mumps, and rubella was compared using a two-tailed Fisher's exact test. The median and mean antibody levels between the HIV and control groups were compared using a two-tailed t-test. Within the HIV group, effects of immunologic and virologic parameters on antibody levels were compared using a twotailed t-test. Correlations between continuous variables were computed using Spearman correlation and test for association. AP value of $<0.05$ was considered significant, and means were given \pm SD (Table 1).
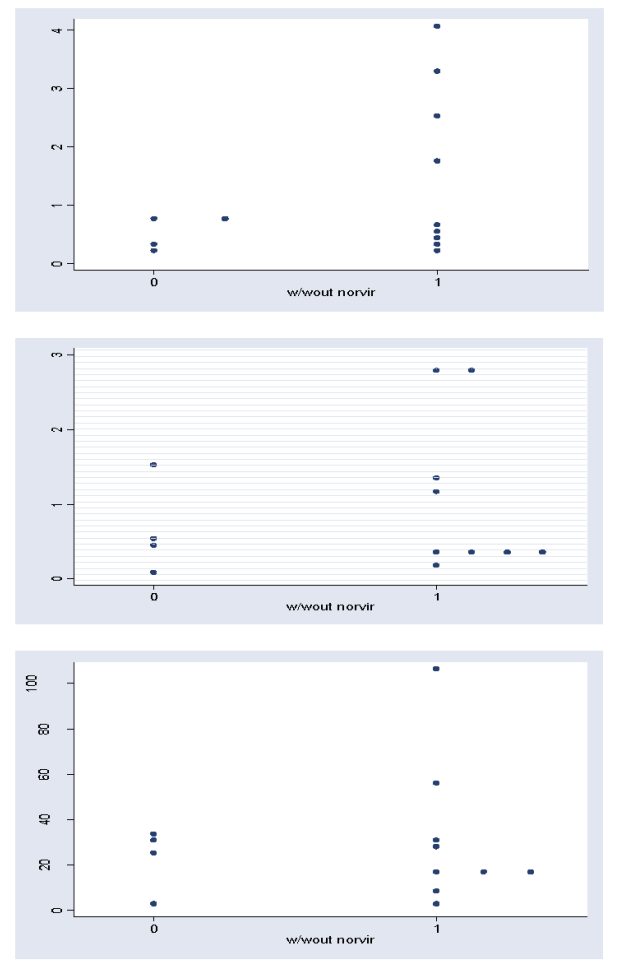

Figure 4: Relationship of treatment regimens with measles, mumps and rubella IgG levels in HIV-Infected Children. 
Citation: Choudhury SA, Matin F (2014) Seroprevalence of Antibodies to Measles, Mumps and Rubella (MMR) Vaccines in Previously Vaccinated Human Immunodeficiency Virus-Infected Children and their Control Counterparts . J Vaccines Vaccin 5: 255. doi: $10.4172 / 2157-7560.1000255$

Page 4 of 5

\begin{tabular}{|c|c|c|c|c|c|c|}
\hline & \multicolumn{2}{|l|}{ Measles } & \multicolumn{2}{|l|}{ Mumps } & \multicolumn{2}{|l|}{ Rubella } \\
\hline & $\begin{array}{l}\text { Responder } \\
(\mathrm{n}=4) \\
\text { Mean } \\
\text { (range) }\end{array}$ & $\begin{array}{l}\text { Non-Responder } \\
(\mathrm{n}=9) \\
\text { Mean } \\
\text { (range) }\end{array}$ & $\begin{array}{l}\text { Responder } \\
(\mathrm{n}=5) \\
\text { Mean } \\
\text { (range) }\end{array}$ & $\begin{array}{l}\text { Non-Responder } \\
(\mathrm{n}=8) \\
\text { Mean } \\
\text { (range) }\end{array}$ & $\begin{array}{l}\text { Responder } \\
(\mathrm{n}=10) \\
\text { Mean } \\
\text { (range) }\end{array}$ & $\begin{array}{l}\text { Non- } \\
\text { Responder } \\
(\mathrm{n}=3) \\
\text { Mean } \\
\text { (range) }\end{array}$ \\
\hline Antibody titers & $\begin{array}{l}2.91 \\
(1.17-4.12)\end{array}$ & $\begin{array}{l}0.48 \\
(0.19-0.75)\end{array}$ & $\begin{array}{l}1.93 \\
(1.1-7.06)\end{array}$ & $\begin{array}{l}0.36 \\
(0.1-0.93)\end{array}$ & $\begin{array}{l}35.97 \\
(15.6-397.6)\end{array}$ & $\begin{array}{l}4.86 \\
(3.5-9)\end{array}$ \\
\hline \multicolumn{7}{|l|}{${ }^{*} \mathrm{P}$ value } \\
\hline $\begin{array}{l}\mathrm{CD} 4 \\
/ \mathrm{mm}^{3}\end{array}$ & $\begin{array}{l}650 \\
(4-1008)\end{array}$ & $\begin{array}{l}512 \\
(2-1078)\end{array}$ & $\begin{array}{l}713 \\
(2-1068)\end{array}$ & $\begin{array}{l}455 \\
(3-1078)\end{array}$ & \begin{tabular}{|l}
534 \\
$(2-1068)$
\end{tabular} & $\begin{array}{l}624 \\
(3-1078)\end{array}$ \\
\hline $\begin{array}{l}\text { Viral load } \\
\text { Copies } \\
\text { RNA/ml }\end{array}$ & $\begin{array}{l}26,130 \\
(2,980-63,900)\end{array}$ & $\begin{array}{l}107,639 \\
(580-583,800)\end{array}$ & $\begin{array}{l}141,422 \\
(6,510-583,800)\end{array}$ & $\begin{array}{l}45,770 \\
(580-269,779)\end{array}$ & $\begin{array}{l}105,091 \\
(580-583,800)\end{array}$ & $\begin{array}{l}7,451 \\
(4,950-10,895)\end{array}$ \\
\hline
\end{tabular}

Table 3: HIV Infected Children: Immunologic and Virologic Parameters. Responder (measles and mumps): > 1.11 ODR; Responder rubella: > $9.9 \mathrm{IU} / \mathrm{ml} .{ }^{\star}$ Two-tailed t- test.

\section{Results}

Of the thirteen HIV-infected children, only four (31\%) ( $\mathrm{p}=0.01)$ and five $(38 \%)(\mathrm{p}=0.04)$ had protective levels $(>1.11$ ODR) of antibodies to measles and mumps, respectively, compared to eleven $(85 \%)$ of the thirteen controls. Antibody levels for mumps were also significantly lower $(\mathrm{p}=0.002)$ in the HIV-infected when compared with the control children. Although the prevalence of protective immunity ( $>9.9 \mathrm{IU} / \mathrm{ml}$ ) for rubella was comparable in HIV-infected and control children, antibody levels were significantly lower $(\mathrm{p}=0.01)$ in HIVinfected children compared to the controls (Table 2).

\section{Correlation between MMR Titers and Other Variables}

MMR titers and age at serology: HIV group: Demonstrated negative correlations with measles IgG $(\mathrm{r}=-0.01, \mathrm{p}=\mathrm{ns})$ and mumps $\operatorname{IgG}$ $(\mathrm{r}=-0.02, \mathrm{p}=\mathrm{ns})$; and positive correlation with rubella $\operatorname{IgG}(\mathrm{r}=0.13$, $\mathrm{p}=\mathrm{ns}$ ) (Figure 1).

Control group: Demonstrated negative correlations with mumps $\operatorname{IgG}(\mathrm{r}=-0.6, \mathrm{p}=0.02)$ and rubella $\operatorname{IgG}(\mathrm{r}=-0.18, \mathrm{p}=\mathrm{ns})$; and positive correlation with measles IgG $(\mathrm{r}=0.13, \mathrm{p}=\mathrm{ns})$ (Figure 2).

Although the mean CD4 counts and viral loads revealed no significant differences within the HIV group between the responders (protective antibody) and non-responders (non-protective antibody), antibody titers were significantly lower $(0.000)$ in the non-responders when compared to the responders (Table 3 ).

MMR titers and CD4 counts in the HIV group: Demonstrated positive correlations with mumps IgG $(\mathrm{r}=0.15, \mathrm{p}=\mathrm{ns})$ and rubella $\operatorname{IgG}$ $(\mathrm{r}=0.5, \mathrm{p}=\mathrm{ns})$; and negative correlation with measles $\operatorname{IgG}(\mathrm{r}=-0.02$, $\mathrm{p}=\mathrm{ns}$ ) (Figure 3).

\section{Discussion}

Introduced to the US in 1989, the two-dose MMR vaccination has dramatically reduced the annual incidence of measles, mumps, and rubella. However, recent US outbreaks of these diseases-even in immune-competent populations-raised concerns regarding the vaccine's efficacy and/or waning immunities to these infectious diseases, not only in the immunocompromised but also in immunecompetent individuals. Although data from our study seems outdated, it may still be useful in explaining the recent outbreaks of these infectious diseases in the US. One limitation of our study, however, was that - when compared to their control counterparts - it could not be determined whether lower immunities in the HIV-infected were the result of primary vaccine failures or waning immunities. Correlation tests determining associations between MMR titers and ages at serology however, demonstrated negative correlations in both HIV and the control group of children (except for rubella in the HIV and measles in the control), raise concerns regarding administration of routine vaccination at a relatively older age or waning immunity possibly contributing to the loss of protective immunities and resurgence of these infectious diseases in the US. Another limitation of our study is that reconstitution of the immune system due to institution of protease inhibitors to the treatment regimen in the HIV group could not be determined. The relationship between treatment regimens and MMR titers as shown in Figure 4, may be misleading and needs clarification that ritonavir was added to their treatment because of clinical or immunologic deterioration; however, the effect of this treatment on immunities could not be verified prospectively.

Despite vaccination efforts and the documentation in 2000 of the elimination of indigenous measles, a marked increase of imported cases and measles outbreaks has been reported in the US in 2011 [20]. Measles, in particular, can be severe with fatal complications in HIVinfected patients and a high case fatality rate of $40 \%$. The consequences of mumps and rubella infections in immunocompromised populations are also anticipated to be severe.

A literature review reveals many faces of outbreaks related to measles, mumps, and rubella in the US. While measles and congenital rubella syndrome occur mostly in unvaccinated susceptible individuals, mumps outbreaks can occur even in adequately (two dose) vaccinated children $[21,22]$ Because waning immunity remains a concern, the authors of this study recommended an additional third 
Citation: Choudhury SA, Matin F (2014) Seroprevalence of Antibodies to Measles, Mumps and Rubella (MMR) Vaccines in Previously Vaccinated Human Immunodeficiency Virus-Infected Children and their Control Counterparts . J Vaccines Vaccin 5: 255. doi: $10.4172 / 2157-7560.1000255$

Page 5 of 5

booster dose for mumps in the face of an outbreak. Measles outbreaks have again been reported not only in travelers but also in susceptible unvaccinated or under-vaccinated children and adults in the US [23]. Meanwhile, rubella outbreaks in unvaccinated adults, complicated by high rates of encephalitis, have been reported elsewhere in the world, such as in Tunisia and Algeria [24]. Because our study results suggest that there may be an increasingly growing population of HIV-infected individuals who are susceptible to measles, mumps, and rubella, either due to primary or secondary (waning immunity) vaccine failures, an additional third booster dose should be considered for this population in the face of an outbreak - even in an adequately vaccinated community (Figure 4).

Another US population at high risk for these infectious diseases includes susceptible pregnant women and risk for congenital infections in their infants. In particular, there is a concern over the development of measles and mumps in this population due to a lack of routine prenatal screening procedures for these infectious diseases. In addition, because HIV-infected individuals are now living longer thanks to the advent of highly active antiretroviral therapy, they may be at a higher risk for developing adverse pregnancy outcomes or congenital infections in their infants. Thus our study results can be extrapolated to analyze risk in susceptible HIV-infected pregnant women who may remain at a higher risk of delivering infants with congenital rubella syndrome and its complications [25]. It is not surprising that studies have pointed to increasing numbers of pregnant women who are susceptible to rubella; one strategy for circumventing this problem is the postnatal immunization of non-immune pregnant women [26].

Our study results show that - compared to their control counterparts - approximately $70 \%$ of HIV-infected children and adolescents remain susceptible to measles and mumps despite two doses of the MMR vaccine; we recommend that antibody titers to MMR be evaluated in HIV-infected children following vaccinations as a means of assessing the primary vaccine response, including subsequent monitoring as deemed clinically necessary. Passive immunoglubulin administration may also be considered for these high risk children when exposed to measles and mumps, regardless of their vaccination status. Further prospective and larger studies may need to be performed in HIV-infected children to determine if lower immunities in this group are due to primary vaccine failure or waning immunity.

\section{References}

1. Galazka AM, Robertson SE, Kraigher A (1999) Mumps and mumps vaccine: a global review. Bull World Health Organ 77: 3-14.

2. Nakajima N, Ueda M, Yamazaki M, Takahashi T, Katayama Y (2013) Optic neuritis following aseptic meningitis associated with modified measles: a case report. Jpn J Infect Dis 66: 320-322.

3. Bale JF Jr (2014) Measles, mumps, rubella, and human parvovirus B19 infections and neurologic disease. Handb Clin Neurol 121: 1345-1353.

4. Coetzee S, Morrow BM, Argent AC (2014) Measles in a South African paediatric intensive care unit: again! J Paediatr Child Health 50: 379-385.

5. Rainwater-Lovett K, Nkamba HC, Mubiana-Mbewe M, Bolton-Moore C, Moss WJ (2013) Changes in measles serostatus among HIV-infected Zambian children initiating antiretroviral therapy before and after the 2010 measles outbreak and supplemental immunization activities. J Infect Dis 208: 1747-1755.
6. Jin $\mathrm{M}, \mathrm{Yu} \mathrm{Y}$, Huang $\mathrm{H}$ (2012) An update on primary ovarian insufficiency. Sci China Life Sci 55: 677-686.

7. Molton J, Smith C, Chaytor S, Maple P, Brown K, et al. (2010) Seroprevalence of common vaccine-preventable viral infections in HIVpositive adults. J Infect 61: 73-80.

8. Merkel M, Ben-Youssef L, Newman LP, Gitome V, Gataguta A, et al. (2014) Seroprevalence of measles IgG among HIV-1-infected and uninfected Kenyan adults. Int J Infect Dis 19: 103-105.

9. Llenas-García J, Rubio R, Hernando A, Arrazola P, Pulido F (2013) Do HIV-positive adult immigrants need to be screened for measles-mumpsrubella and varicella zoster virus immunization? AIDS Care 25: 980-989.

10. Floridia M, Pinnetti C, Ravizza M, Tibaldi C, Sansone M, et al. (2011) Rubella susceptibility profile in pregnant women with HIV. Clin Infect Dis 52: 960-962.

11. Papania MJ, Wallace GS, Rota PA, Icenogle JP, Fiebelkorn AP, et al. (2014) Elimination of endemic measles, rubella, and congenital rubella syndrome from the Western hemisphere: the US experience. JAMA Pediatr 168: 148-155.

12. Muscat M, Shefer A, Ben Mamou M, Spataru R, Jankovic D, et al. (2014) The state of measles and rubella in the WHO European Region, 2013. Clin Microbiol Infect 20 Suppl 5: 12-18.

13. Sane J, Gouma S, Koopmans M, de Melker H, Swaan C, et al. (2014) Epidemic of mumps among vaccinated persons, The Netherlands, 2009-2012. Emerg Infect Dis 20: 643-648.

14. McLean HQ, Fiebelkorn AP, Temte JL, Wallace GS; Centers for Disease Control and Prevention (2013) Prevention of measles, rubella, congenital rubella syndrome, and mumps, 2013: summary recommendations of the Advisory Committee on Immunization Practices (ACIP). MMWR Recomm Rep 62: 1-34.

15. Centers for Disease Control and Prevention (1994). Revised classification system for human immunodeficiency virus infection in children less than 13 years of age. MMWR 43:1-19.

16. Norrby E (1985) Measles virus. (4th edn), American Society for Microbiology, Washington DC, 769-773.

17. Norrby E (1985) Measles virus. (4th edn), American Society for Microbiology, Washington DC, 774-778.

18. Balfour HH Jr, Groth KE, Edelman CK, Amren DP, Best JM, et al. (1981) Rubella viraemia and antibody responses after rubella vaccination and reimmunization. Lancet 1: 1078-1080.

19. Greaves WL, Orenstein WA, Hinman AR, Nersesian WS (1983) Clinical efficacy of rubella vaccine. Pediatr Infect Dis 2: 284-286.

20. Ortega-Sanchez IR, Vijayaraghavan M, Barskey AE, Wallace GS (2014) The economic burden of sixteen measles outbreaks on United States public health departments in 2011. Vaccine 32: 1311-1317.

21. Aasheim ET, Inns T, Trindall A, Emmett L, Brown KE, et al. (2014) Outbreak of mumps in a school setting, United Kingdom, 2013. Hum Vaccin Immunother 10.

22. Abrams S, Beutels P, Hens N (2014) Assessing mumps outbreak risk in highly vaccinated populations using spatial seroprevalence data. Am J Epidemiol 179: 1006-1017.

23. Gahr P, DeVries AS, Wallace G, Miller C, Kenyon C, et al. (2014) An outbreak of measles in an undervaccinated community. Pediatrics 134 : e220-228.

24. Grangeot-Keros L, Bouthry E, Vauloup-Fellous C (2014) Rubella: a current issue? Presse Med 43: 698-705.

25. Toizumi M, Motomura H, Vo HM, Takahashi K, Pham E, et al. (2014) Mortality associated with pulmonary hypertension in congenital rubella syndrome. Pediatrics 134: e519-526.

26. Skidmore S, Boxall E, Lord S (2014) Is the MMR vaccination programme failing to protect women against rubella infection? Epidemiol Infect 142: 1114-1117. 